\title{
An economic Evaluation of training and its Effect on employee performance in Building Construction Directory of Sulaimani province - Kurdistan region
}

\section{Younis A.Ahmed}

Department of Economic, College of Administration and Economics, University of Sulaimani, Sulaimani, Iraq

uns.ahmad@univsul.edu.iq

\section{Dalia Khalid Faeq}

Department of Administration and Accounting, Faculty of Humanities and Social science, University of Koya, Koya, Iraq

da1980 lia@yahoo.com

\section{ARTICLE INFO}

\section{Article History:}

Received:

Accepted: 28/7/2019

Published: Spring2020

Keywords: Training,

Employee performance,

Building Construction

Directory, Sulaimani

Province- Kurdistan

region, Descriptive

Analytical Method.

\section{ABSTRACT}

Training would provide opportunities to the employees to have a better career life and get better position in the organization. This paper attempts to investigate the effect of training on employee performance. Likewise, for answering study questions "Whether training has a vital effect on employee Performance of Building Construction directory of Sulaimani province - Kurdistan region? To achieve this objective and answering this question , the descriptive analytical method with linear regression model were applied, and the data collected through primary source that are from questionnaires of (70) employees which working in Building Construction Directory of Sulaimani province.The results show that dimensions of training has a strong positive significant influence on employee performance and the regression coefficient 


\section{QALAAI ZANISTSCIENTIFIC JOURNAL \\ A Scientific Quarterly Refereed Journal Issued by Lebanese French University - Erbil, Kurdistan, Iraq \\ Vol. (5), No (2), Spring 2020 \\ ISSN 2518-6566 (Online) - ISSN 2518-6558 (Print)}

Doi:

10.25212/lfu.qzj.5.2.30 of responsiveness is 0.76 with p-value of 0.000 , which indicates that the increase in training level by one percent, employee performance increases by 0.76 percent. To conclude, some of suggestion provides to help managers of Building Construction Directory of Sulaimani province to offer regular and different levels of training to guarantee employee desires and incrase work performance.

\section{INTRODUCTION}

The employees in any organization are the most important resources. In addition to the technological change, Training is the essential factor that leads to increase in a quality of products, shorten the time to accomplish tasks, reduce costs and raise the efficiency of the work, especially when the employee have the skills and knowledge ensemble their jobs. Making organizations interact with these rapid changes and work to assess their situations in filling any deficiency in the skills of its employees by having training (Sims, 2002). In order to facility employee progression, many organizations determine budget to train and develop their employees. According to (Obisi, 2011). The main objective of training program is to add value to human resource. Furthermore, the benefits of training for both (organizations and employees). For organization, training leads to increase profitability, while for the employees, training leads to improve job and increase wages and salary. Moreover, Kamoche and Mueller (1998) mentioned that training should lead to enhance learning, to raise employee performance and ultimately a higher return to investment (in training) for the firm.

\section{Problem Statement}

The current study adopts an important topic as a framework involving the revitalization of the organization's effectiveness through the availability requirements 


\section{QALAAI ZANISTSCIENTIFIC JOURNAL \\ A Scientific Quarterly Refereed Journal Issued by Lebanese French University - Erbil, Kurdistan, Iraq \\ Vol. (5), No (2), Spring 2020 \\ ISSN 2518-6566 (Online) - ISSN 2518-6558 (Print)}

of the basic system for organizational development in the construction directory under study. Despite the facts that the building construction directory provides training to its employees, but there are employee performance still not meet require level. Therefore, the study problem can determine by the following question: "Does training affect employee performance"?

\section{The importance of the study:}

The importance of this study is being considered as:

1. The construction sector is considered to be one of the most sectors that need modern and sophisticated training programs.

2. To the best knowledge of researchers, no current literature on the effect of training on employee performance in the construction building directory Kurdistan Region. Thus, the current study is going to fill up some gap by adding one empirical study to the existing knowleages.

\section{The objectives of Study:}

This study aims to achieve the following specific objectives:

1. To clarify the concepts of training and employee performance.

2. To identify the most important factors that enhance employee performance.

3. To determine the impact of training on employee performance.

\section{Study Hypotheses:}

Based on the objectives above, this study will examine the below hypothesis : "Employee performance is significantly related to changes in training".

The above-mentioned is the basic principle of the study and the rest of the paper are organized as follows. Section 2 discusses the theoretical framework. Section 3 Empirical literature reviews related studies. Section 4 presents the methodology and data collection. Section 5 provides the main Results and 


\section{QALAAI ZANISTSCIENTIFIC JOURNAL}

A Scientific Quarterly Refereed Journal Issued by Lebanese French University - Erbil, Kurdistan, Iraq

Vol. (5), No (2), Spring 2020

ISSN 2518-6566 (Online) - ISSN 2518-6558 (Print)

Interpretation. Section 6 provides the main conclusion and recommendation. Limitation of the study is presented in the last section.

\section{Theoretical Framework}

The main goal of the presenting theoretical framework is to understand the basic fundamentals of the study. Consequently; current study tries to present the main framework of the study as follows:

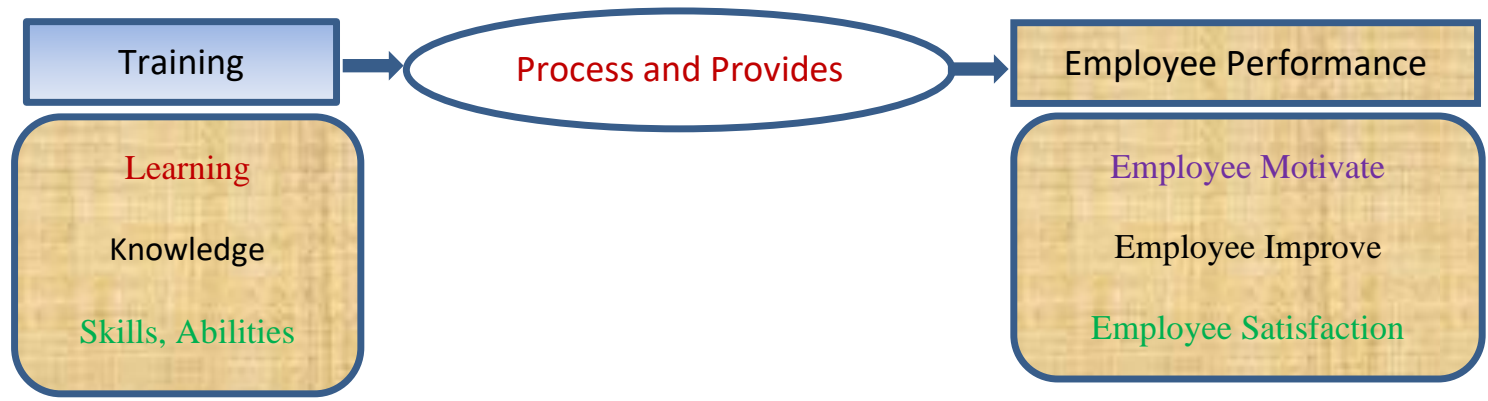

Figure 1: Theoretical Framework for Training and employee performance

The figure 1 shows the designed framework of this study is created to show the effect of Training on Employee Performance.

\subsection{Training}

\begin{tabular}{|c|l|}
\hline Authors & \multicolumn{1}{|c|}{ Defination } \\
\hline Flippo, 1976 & $\begin{array}{l}\text { Training is the act of increasing knowledge and skills of an } \\
\text { employee for doing a particular job. }\end{array}$ \\
\hline Sims, 2002 & $\begin{array}{l}\text { Training focuses on present jobs while development prepares } \\
\text { employees for possible future jobs. }\end{array}$ \\
\hline Goldstein and Ford, 2002 & $\begin{array}{l}\text { Training is an organized method of learning and development } \\
\text { which expand the efficiency of individual, group, and the } \\
\text { organization. }\end{array}$ \\
\hline Aswathappa, 2005 & $\begin{array}{l}\text { Training indicates the process involved in improving the } \\
\text { aptitudes, skills and abilities of the employees to perform specific } \\
\text { jobs, and training helps in updating old talents and developing }\end{array}$ \\
\hline
\end{tabular}


Vol. (5), No (2), Spring 2020

\begin{tabular}{|c|l|}
\hline & $\begin{array}{l}\text { new ones, Successful candidates placed on the jobs need training } \\
\text { to perform their duties effectively. }\end{array}$ \\
\hline Armstrong \& Taylor, 2014 & $\begin{array}{l}\text { Training is a systematic development of the knowledge, skills and } \\
\text { attitudes required by an individual to perform adequately a given } \\
\text { task or job. }\end{array}$ \\
\hline
\end{tabular}

The organization should properly evaluate their training program by seeing that their organization objectives and missions are achieved or not, and training cannot only change the ability of workforce not only concerning performing their current job, but also aid them in the fulfillment of future expected task so for this reason it's a practice that cannot be discarded form an organizations. Thus training is a learning process to a chive a current task and prepare the employee to transfer from one stage to another stage which is more developed to enable the employees to face challenges and innovations happen in the organization even internally or externally (Obisi, 2011).

\subsubsection{Importance and Benefit of Training:}

1. The high productivity of the trainee employee as a result of increasing his knowledge and develop his skills and refining his abilities.

2. Reduce the rates of mistakes committed during work, leading to mastery of work and thus to raise the level of customer satisfaction.

3. Raise the morale of the employees as a result of raising their skills and abilities to reach the level required to perform their functions, which leads to a reduction in the turnover rate and the rates of absenteeism.

4. Improve confidence between the president and the subordinate and strengthen relations between them.

5. Increase the ability of staff to exchange views and information with the rest of the participants in the courses.

\subsubsection{Practical Stages Training}

The success of the training strategy process depends on the extent of good planning before, during and after the actual training takes place. The training strategy process 
should be seen as a multi- faceted, coherent and complementary process. The process can be defined in four stages:

1. Identification of training needs

2. Design of the training program

3. Implementation of the training program

4. Evaluation of the training program

\subsection{Employee performance:}

\begin{tabular}{|c|l|}
\hline Authors & \multicolumn{1}{|c|}{ Defination } \\
\hline Rothman \& Coetzer, 2003 & $\begin{array}{l}\text { Performance is the accomplishment of a given task measured } \\
\text { against pre-set standards of accuracy,completeness, cost, and } \\
\text { speed, the initiatives they take, their creativity in solving problems } \\
\text { and the resourcefulness in the way they utilise their resources, } \\
\text { time and energy. }\end{array}$ \\
\hline Kinnie et. al , 2005 & $\begin{array}{l}\text { Employee performance is a function of organizational } \\
\text { performance as employee performance influences general } \\
\text { organizational performance. }\end{array}$ \\
\hline Sultana et. al, 2013 & $\begin{array}{l}\text { Performance is achievement of specific tasks measured against } \\
\text { predetermined or identified standards of accuracy, completeness, } \\
\text { cost and speed. Employee performance can be manifested in } \\
\text { improvement in production, easiness in using the new } \\
\text { technology, highly motivated workers. }\end{array}$ \\
\hline
\end{tabular}

There is a difference between the organizations that train their employees and those who do not by their performance and facing their competitor (Pfeffer, 1994). An organization that gives worth to knowledge as a source of gaining competitive edge than competitors, should build up system that ensure constant learning, and on the effective way of doing so is training( Leonard-Barton, 1992). When the organization has a plan need to be achieved, the way of implementing that plan it can be defined as performance therefore required skills and knowledge is necessary to complete the task properly otherwise the organization need to find away to enhance the performance by training.

\subsection{The relationship between Training and employees performance}




\section{QALAAI ZANISTSCIENTIFIC JOURNAL \\ A Scientific Quarterly Refereed Journal Issued by Lebanese French University - Erbil, Kurdistan, Iraq \\ Vol. (5), No (2), Spring 2020 \\ ISSN 2518-6566 (Online) - ISSN 2518-6558 (Print)}

Obisi(2001) reported that training is a systematic process of enhancing the knowledge, skills and attitude, hence leads to satisfactory performance by the employees at job. He mentioned that the need and objectives of the training program should be identified before offering it to the employees. According to (Labadarioset al 2005) Implementing training programs as a solution to covering performance issues such as filling the gap between the standard and the actual performance is an effective way of improving employee performance. Also he confirm that elaborate the concept by stating that training facilitate organization to recognize that its workers are not performing well and a thus their knowledge, skills and attitudes needs to be molded according to the firm needs .Emphasized by(Sahinidis\& Bouris 2008) learning through training influence the organizational performance by greater employee performance, and is said to be a key factor in the achievement of corporate goals. It is important the realization of company to determine its need from employees skill and ability to develop training program. Furthermore, (McGill \& Slocum 1993) Employee performance, achieved through training, refers to immediate improvements in the knowledge, skills and abilities to carry out job related work.

Besides, the effect of training on employee performance can be classified in to some main points as following:

First: Renew the employees knowledge : Described that organizations are required to develop and maintain such learning environment for the employees that expand the knowledge, ability and skill of organization and competitive ability. Effective training programs helps employees to get acquaintance with the desired new technological advancement, also gaining full command on the competencies and skills required to perform at $\mathrm{s}$ particular job and to void on the job errors and mistakes (Brinkerhoff ,O.R.,2005).

Second: Motivate employees: A good training programme will lead employees' to increase confidence, motivations and obtain high loyalty. Employees have no feeling about their organizations, if they think that their organizations are not caring about them (Garger ,1999). 


\section{QALAAI ZANISTSCIENTIFIC JOURNAL \\ A Scientific Quarterly Refereed Journal Issued by Lebanese French University - Erbil, Kurdistan, Iraq \\ Vol. (5), No (2), Spring 2020 \\ ISSN 2518-6566 (Online) - ISSN 2518-6558 (Print)}

Third: Decrease stress for employees: The more control workers have over their work and the way they do it and the more they participate in decisions that concern their jobs, the less likely they are to experience work stress (Cox et al .,2005).

Fourth: Improve the quality of employees work: Training is the crux of better organizational management, as it makes employees more efficient and effective (Scott,1954) Furthermore, mentioned that a well-trained worker is able to make a best use of organizational resources along with minimum level of wastages.

Fifth: Prepare employees for a new task: Training sessions accelerate the initiative ability and creativity of the workforce and facilitate to avoid human resource obsolescence, which may occur because of demographic factors such as age, attitude or the inability to cope with the technological changes (Arnoff, 1971).

Sixth: Increase employee satisfaction: Employee performance is higher in happy and satisfied workers and the management find it easy to motivate high performers to attain firm targets. Firms which are providing the training and development programs for their employees are achieving high level of employee satisfaction and low employee turnover (Wagner, 2000).

\section{Literature Review}

For better understanding, this section provides an overview of the previous study related training and employee performance. In fact; there are several empirical studies on the effect of training on employee performance.

\begin{tabular}{|c|l|}
\hline Studies & \multicolumn{1}{|c|}{ Result, Finding and Conclusion } \\
\hline \multirow{2}{*}{ Wright \& Geroy ,2001 } & $\begin{array}{l}\text { Employee competencies change through } \\
\text { effective training programs. Training not only } \\
\text { improve the performance of the employees, but } \\
\text { also improve the knowledge, skills an attitude of } \\
\text { the workers necessary for the future job. }\end{array}$ \\
\hline
\end{tabular}




\begin{tabular}{|c|l|}
\hline Ahmad \& Bakar, 2003 & $\begin{array}{l}\text { High level of employee commitment and } \\
\text { improves the performance are achieved } \\
\text { through training. }\end{array}$ \\
\hline Sahinidis \& Bouris, 2008 & $\begin{array}{l}\text { Significant correlation between the employee's } \\
\text { perceived training effectiveness and their } \\
\text { commitment, job satisfaction and motivation. }\end{array}$ \\
\hline Naqvi, \& Khan, 2013 & $\begin{array}{l}\text { Significant and positive correlation between } \\
\text { training and organization performance. }\end{array}$ \\
\hline De Mel et. al, 2014 & $\begin{array}{l}\text { Training may have more profitability and more } \\
\text { effective for new owners. }\end{array}$ \\
\hline Asfaw et. al, 2015 & $\begin{array}{l}\text { Training had positively correlated with } \\
\text { employee performance and effectiveness. }\end{array}$ \\
\hline Hafeez \& Jinnah, 2015 & $\begin{array}{l}\text { Apositive significant relationship between the } \\
\text { employee gets training and efficient. }\end{array}$ \\
\hline Konings \& Vanormelingen, 2015 & $\begin{array}{l}\text { The productivity premium of a trained worker is } \\
\text { substantially higher compared to the wage } \\
\text { premium. }\end{array}$ \\
\hline
\end{tabular}

From above present, despite differences from activity to other, but literature shows that there is a positive effect of training on employee performance and most of the previous studies proved that there is a strong positive relationship between human resource management practices and employee performance. Likewise, to the best knowledge of this researcher, no current international literature on effect of training on employee performance of Building Construction directory of Sulaimani province Kurdistan Region.

\section{Methodology and Data collection}

This section provides the study sample and data collection. The major parts of this section are the model specification and variables as follow:

Population and study sample: The target population selected for this study is Building Construction Directory of Sulaimani province - Kurdistan region. While the study sample includes employees who worked in Building Construction Directory. 


\section{QALAAI ZANISTSCIENTIFIC JOURNAL \\ A Scientific Quarterly Refereed Journal Issued by Lebanese French University - Erbil, Kurdistan, Iraq \\ Vol. (5), No (2), Spring 2020 \\ ISSN 2518-6566 (Online) - ISSN 2518-6558 (Print)}

Data Collection: The survey type of research is applied by using the questionnaire during the period (1 Jan. to 30 Jan. / 2017), testing on a population of Building Construction Directory to find out the performance of their employees as a result of training provided by their Directorate. The questioner modified from previous researcher Muhamad,F. (2015).The total number of samples which is surveyed from the $(70)$ employees, which has taken the $(85.7 \%)$ of the total employee of Building Construction Directory.

Method and Model estimation: This study is based on primary data by applying the descriptive analytical method (DAM). The study model was based on the previous studies and literature review, which relate to the subject of the study. Furthermore, current study describes the training (independent variable) and employee performance (dependent variable).

$Y=C+\beta 1 X 1+U$

$\mathbf{Y}=$ Employee Performance

$\mathbf{X}=$ Training

C= Constant

$\mathbf{U}=$ Error Term

\section{Results and Interpretation}

The results of the study were carried out through applying SPSS to determine reliability, descriptive statistics, correlation, factor analysis and multiple regressions.

9.1 Respondents Profile: Respondents are asked to give answers of the questions related to their personal information. The profile of a respondent as shown in table (1). 


\section{QALAAI ZANISTSCIENTIFIC JOURNAL}

A Scientific Quarterly Refereed Journal Issued by Lebanese French University - Erbil, Kurdistan, Iraq

Vol. (5), No (2), Spring 2020

ISSN 2518-6566 (Online) - ISSN 2518-6558 (Print)

\begin{tabular}{|c|c|c|c|}
\hline Information & Item & Frequencey & Percentage (\%) \\
\hline \multirow{2}{*}{ Gender } & male & 17 & 28.3 \\
\hline & female & 43 & 71.7 \\
\hline \multirow{3}{*}{ Age } & Less than 30 year & 6 & 10 \\
\hline & 31 to 40 & 40 & 66.7 \\
\hline & More than 40 year & 1 & 23.3 \\
\hline \multirow{3}{*}{ Married statue } & married & 9 & 80 \\
\hline & single & 48 & 15 \\
\hline & others & 3 & 5 \\
\hline \multirow{3}{*}{ Qualification } & under graduate & 9 & 15 \\
\hline & B.Sc. & 49 & 81.7 \\
\hline & M.Sc. & 2 & 3.3 \\
\hline \multirow{4}{*}{ Experience } & Less than 5 year & 5 & 8.3 \\
\hline & 6 to 15 year & 41 & 68.3 \\
\hline & 16 to 26 year & 10 & 16.7 \\
\hline & More than 26 year & 4 & 6.7 \\
\hline \multirow{3}{*}{ Training } & Less than 5 time & 11 & 18.3 \\
\hline & 5 to 10 times & 39 & 65 \\
\hline & More than 10 times & 10 & 16.7 \\
\hline \multicolumn{2}{|c|}{ Total } & 60 & 100 \\
\hline
\end{tabular}

Source: Prepared by researchers based on Field Survey from 70 employees, 2017.

The profile of a respondent shows the majority of the respondents belong to the age group (30-40 years). Most of them are female (71.7\%) and the male (28.3\%), and number of training they get (5 to 10 ) both male and female persons are $(65 \%)$. Moreover, the most of them were bound in the marital bond and had completed the B.Sc. level of their education.

9.2 Scale Reliability: In addition, to determine Scale reliability, Cronbach's alpha coefficient was used to check and evaluate the questioner which is acceptable by seeing the value of Cronbach's ( $\alpha=0.6)$.

Table 2. Cronbach's alpha coefficient for Elements

\begin{tabular}{|c|c|c|}
\hline Type of Variables & Number of questions & Cronbach's alpha \\
\hline Independent variable (Training) & 9 & 0.925 \\
\hline Dependent variable (Employ Performance) & 8 & 0.942 \\
\hline
\end{tabular}




\section{Total}

\section{7}

Source: Prepared by the researchers based on SPSS.

Table (2) shows the overall Cronbach's alpha value in all has $(\alpha>0.6)$, which indicate the questionnaire used in the study can be regarded to be reliable.

9.3 Descriptive Statistics: This information indicates the level of agreeableness and disagreeableness of the respondents by seeing the value of mean.

Table 3. Result of Mean and Std. Deviation

\begin{tabular}{|l|c|c|}
\hline \multicolumn{1}{|c|}{ Statement } & Mean & $\begin{array}{c}\text { Std. } \\
\text { Deviation }\end{array}$ \\
\hline Training decrease the daily mistake & 4.2000 & .93519 \\
\hline Training reduced the stress of work & 4.3333 & 1.20263 \\
\hline Training reduced the disparity in ability of creation & 3.3167 & .92958 \\
\hline $\begin{array}{l}\text { Training contributes a competition between employee for } \\
\text { better performance }\end{array}$ & 3.2667 & 1.0393 \\
\hline Increase knowledge and work experience after training & 3.9667 & 1.0571 \\
\hline Training contributes in distinction in my work & 3.0833 & .82937 \\
\hline Training contributes to the speed of work performance & 4.2000 & .98806 \\
\hline Training achieved knowledge and ability of practice & 3.8833 & .94046 \\
\hline
\end{tabular}

Source: Prepared by researchers based on SPSS

Table (3) shows that the majority of the respondents surveyed are agree on the statement that training has a positive effect on employee performance of Building Construction Directory of Sulaimani province. From table (3), in general the mean of all statements goes toward (4) which shows that the majority of the respondents surveyed are agree on the statement that training has positive effect on employee performance and the training contribute to speed of activity by (0.98). While, the level of the effect different from statement to others, for example the ranking of Training decrees stress of work was highest with a mean (4.33), were the Training increase speed of performance and decreases daily mistake have 2 nd with the mean of (4.200). 


\subsection{Pearson Correlation}

It is defined as a 'relationship amongst variables, in terms of the strength. Sig (2Tailed) value shows that the relationships between variables are statistically significant or not.

\section{Table 4. Result of Pearson Correlation Coefficient}

\begin{tabular}{|c|c|c|c|}
\hline Statement & $\begin{array}{c}\text { Pearson } \\
\text { correlation(r) }\end{array}$ & $\begin{array}{c}\text { Significant } \\
\text { level }\end{array}$ & Decision \\
\hline Training achieved knowledge and ability of practice & 0.71 & 0.000 & Reject $\mathrm{H}_{0}$ \\
\hline Training contributes to the speed of work performance & 0.67 & 0.000 & Reject $\mathrm{H}_{0}$ \\
\hline Training contributes in distinction in my work & 0.35 & 0.005 & Reject $\mathrm{H}_{0}$ \\
\hline Increase knowledge and work experience after training & 0.66 & 0.000 & Reject $\mathrm{H}_{0}$ \\
\hline $\begin{array}{l}\text { Training contributes a competition between employee } \\
\text { for better performance }\end{array}$ & 0.75 & 0.000 & Reject $\mathrm{H}_{0}$ \\
\hline Training reduced the disparity in ability of creation & 0.76 & 0.000 & Reject $\mathrm{H}_{0}$ \\
\hline Training reduced the stress of work & 0.65 & 0.000 & Reject $\mathrm{H}_{0}$ \\
\hline Training decrease the daily mistake & 0.55 & 0.000 & Reject $\mathrm{H}_{0}$ \\
\hline \multirow{2}{*}{\multicolumn{4}{|c|}{$\begin{array}{l}\text { Note: Pallant (2001) suggested the following interpretation of } r \text {-value [cited from Cohen, 1988]. This value } \\
\text { will indicate the strength of the relationship between two variables. } \\
\text { A: } r=0.10 \text { to } .29 \text { or } r=-0.10 \text { to }-0.29 \text { weak } \\
\text { B: } r=0.30 \text { to } .49 \text { or } r=-0.30 \text { to }-0.49 \text { Medium } \\
\text { C: } r=0.50 \text { to } 1.0 \text { or } r=-0.50 \text { to }-1.0 \text { strong } \\
\text { Note: In the Pearson correlation analysis the number of variables (dependent and independent) is two, and the } \\
\text { number of sample size (N) is } 60 \text {. }\end{array}$}} \\
\hline & & & \\
\hline \multicolumn{4}{|l|}{ Note: The significant level is 0.05 ( $\left.\mathrm{p}_{-} 0.05\right)$. } \\
\hline $\begin{array}{l}\text { ject }\left(\mathrm{H}_{0}\right) \text { : There is a negative relationship between } \\
\text { cept }\left(\mathrm{H}_{1}\right) \text { : There is a positive relationship between }\end{array}$ & and emplo & & \\
\hline
\end{tabular}

Source: Prepared by the researchers based on SPSS.

Table(4) indicates that the $p$-value for all statements is less than 0.05 , which mean that the relationships between variables are statistically significant, therefore, as a whole, we reject the null hypothesis ( $\mathrm{HO})$ and accept $(\mathrm{H} 1)$. Thus, concluded that there is a strong positive relationship between training and employee performance in the Building Construction Directory of Sulaimani province. For instance, the highest strongest positive correlation with training (0.76) and (training contributes a competition between employee for better performance) the 2nd highest, strongest 
positive correlation with a value of $(0.754)$. Besides, the others also have a strong positive correlation with an independent variable.

\subsection{Regression Analysis (Hypotheses Testing)}

Regression analysis is a statistical procedure used for estimating the effect of Training on Employee Performance. The coefficient of the regression and tests for check the model adequacy are presented in Table (5).

Table 5. Regression Result of Training and Employee performance

\begin{tabular}{|c|c|c|c|c|c|c|}
\hline Variable & Constant & $\begin{array}{c}\text { Coefficients } \\
\text { Beta }\end{array}$ & t-value & Sig. & $\begin{array}{c}\text { Durbin } \\
\text { Watson }\end{array}$ & Decision \\
\hline Training & 8.351 & 0.764 & 9.026 & 0.000 & 1.930 & Reject $\mathrm{H}_{0}$ \\
\hline $\mathrm{R}^{2}$ & 0.580 & & F- test & 81.460 & & \\
\hline
\end{tabular}

Note: when ( $\mathrm{t}-$ value) is greater than 2 and ( $\mathrm{p}$-value) is less than 0.05 , null hypothesis is rejected.

Note:

Reject $\left(H_{0}\right)$ : There is a negative relationship between training and employee performance. Accept $\left(\mathrm{H}_{1}\right)$ : There is a positive relationship between training and employee performance.

Source: Prepared by the researcher based on SPSS.

From table (5) as a whole, is a fit to the data, the regression model interpretation ability for training represented in $\left(\mathrm{R}^{2}\right)$ coefficient was $(0.58)$ indicating that $58 \%$ of changes in employee performance level are interpreted by training. From the model estimation, the value of Beta (standardized coefficient) indicates that the contribution of independent variable (training) for its dependent variable (employee performance). Holding other variables constant, the regression coefficient of responsiveness is 0.76 with $p$-value of 0.000 indicates that the increase in responsiveness by one percent, employee performance increases by 0.76 percent. 


\section{QALAAI ZANISTSCIENTIFIC JOURNAL \\ A Scientific Quarterly Refereed Journal Issued by Lebanese French University - Erbil, Kurdistan, Iraq \\ Vol. (5), No (2), Spring 2020 \\ ISSN 2518-6566 (Online) - ISSN 2518-6558 (Print)}

Also, the above analysis, as shown in table (5), based on the (t-test, F-test and $\mathrm{p}$ value) estimation was significant at the $5 \%$ significance level and consistent theoretically. Which indicate that our hypothesis is rejected. This result consists with previous result by (Hafeez \& Jinnah 2015) and (Tahir \& Yousafzai, kh.et al 2014).

\section{Conclusion and Recommendation}

Training is an important function for an organization to get skilled and knowledge employees for better performance. Training would provide opportunities to the employees to make a better positions in the organization and obtain better career life.Consequently, organization's efficiency would be increased. On the other hand, employees are the resources and assets of an organization if they are skilled. In the light of the above discussion, present study results show that dimensions of training has a strong positive significant influence on employee performance and the regression coefficient of responsiveness is 0.76 with $p$-value of 0.000 , which indicates that the increase in training level by one percent, employee performance increases by 0.76 percent. Finally, understanding the relationship between training and employee performance will help managers of Building Construction Directory to provide more and different level of training program on a regular basis to guarantee that they are meeting employee desires and practice what they learned in their work.

\section{Limitation of the study and future research}

Current study concern only on employee of Building Construction Directory of Sulaimani province, as well as, only on the elements of training. Thus, for the future research it is suggested that similar study may be done on 'different sectors' and on a 'bigger sample size'.

\section{REFERENCES:}




\section{QALAAI ZANISTSCIENTIFIC JOURNAL \\ A Scientific Quarterly Refereed Journal Issued by Lebanese French University - Erbil, Kurdistan, Iraq \\ Vol. (5), No (2), Spring 2020 \\ ISSN 2518-6566 (Online) - ISSN 2518-6558 (Print)}

Ahmad, K. Z., \& Bakar, R. A. (2003). The association between training and organizational commitment among white-collar workers in Malaysia. International journal of training and development, 7(3), 166-185.

Armstrong, M., \& Taylor, S. (2014). Armstrong's handbook of human resource management practice. Kogan Page Publishers.

Aronoff, J., \& Litwin, G. H. (1971). Achievement motivation training and executive advancement. The Journal of Applied Behavioral Science, 7(2), 215-229. Arnoff, E. L. (1971). Successful models I have known. Decision Sciences, 2(2), 141-148.

Asfaw ,A, M. Argaw ,M.and Bayissa ,L.(2015). The impact of training and development on employee performaqnce and effectiveness .A case study of distinict five administration office ,bole sub city ,adis ababa, Ethiopia . Journal of Human Resource and Sustainability Studies, 2015, 3, 188-202

http://www.scirp.org/journal/jhrss http://dx.doi.org/10.4236/jhrss.2015.34025

Aswathappa, K. (2005). Human resource and personnel management. Tata McGraw-Hill Education.

Beardwell, J., \& Claydon, T. (Eds.). (2010). Human resource management: A contemporary approach. Financial Times/Prentice Hall.

Brinkerhoff, R. O. (2005). The success case method: A strategic evaluation approach to increasing the value and effect of training. Advances in Developing Human Resources, 7(1), 86-101.

Cox, T., Griffiths, A., \& Leka, S. (2005). Work Organization and Work-Related Stress. Occupational Hygiene, Third Edition, 421-432.

De Mel, S., McKenzie, D., \& Woodruff, C. (2014). Business training and female enterprise start-up, growth, and dynamics: Experimental evidence from Sri Lanka. Journal of Development Economics, 106, 199-210.

Flippo, E. B. (1976). Principles of personnel management. McGraw-Hill. 


\section{QALAAI ZANISTSCIENTIFIC JOURNAL \\ A Scientific Quarterly Refereed Journal Issued by Lebanese French University - Erbil, Kurdistan, Iraq \\ Vol. (5), No (2), Spring 2020 \\ ISSN 2518-6566 (Online) - ISSN 2518-6558 (Print)}

Garger, E. M. (1999). Goodbye training, hello learning. WORKFORCE-COSTA MESA-, 78, 3543.

Goldstein, I. L., \& Ford, J. K. (2002). Training in organizations Belmont. CA: Wadsworth.

Guest, D. E. (1997). Human resource management and performance: a review and research agenda. International journal of human resource management, 8(3), 263-276.

Hafeez, U., \& Akbar, W. (2015). “Impact of Training on Employees Performance”(Evidence from Pharmaceutical Companies in Karachi, Pakistan). Business Management and Strategy, 6(1), 49-64.

Heneman ,H,G. Schwab, D. \& Dyer, Lee (2000). Personnel/Human Resource Management: 4th ed.: Universal Book Stall; New Delhi pp 511-513

https://www.amazon.com/Personnel-Resource-Management...Henem

Kamoche, K., \& Mueller, F. (1998). Human resource management and the appropriation learning perspective. Human Relations, 51(8), 1033-1060.

Kinnie, N., Hutchinson, S., Purcell, J., Rayton, B., \& Swart, J. (2005). Satisfaction with HR practices and commitment to the organisation: why one size does not fit all. Human Resource Management Journal, 15(4), 9-29.

Konings, J., \& Vanormelingen, S. (2015). The impact of training on productivity and wages: firm-level evidence. Review of Economics and Statistics, 97(2), 485-4

Labadarios, D., Steyn, N. P., Maunder, E., MacIntryre, U., Gericke, G., Swart, R., ... \& Nel, J. H. (2005). The national food consumption survey (NFCS): South Africa, 1999. Public health nutrition, 8(05), 533-543.

Leonard-Barton, D. (1992). Core capabilities and core rigidities: A paradox in managing new product development. Strategic management journal, 13(S1), 111-125.

McGill, M. E., \& Slocum, J. W. (1993). Unlearning the organization. Organizational dynamics, $22(2), 67-79$. 


\section{QALAAI ZANISTSCIENTIFIC JOURNAL \\ A Scientific Quarterly Refereed Journal Issued by Lebanese French University - Erbil, Kurdistan, Iraq \\ Vol. (5), No (2), Spring 2020 \\ ISSN 2518-6566 (Online) - ISSN 2518-6558 (Print)}

Naqvi, S. M. H., \& Khan, M. A. (2013). Employees Training and Organizational Performance: Mediation by Employees Performance.

Obisi, C. (2011). Employee Training and Development in Nigerian Organisaitons: Some Observations and Agenda for Research. Australian Journal of Business and Management Research, 1(9), 82.

Pfeffer, J. (1994). Competitive advantage through people. California management review, $36(2), 9-28$.

Purcell, J. (2003). Understanding the people and performance link: unlocking the black box. CIPD Publishing.

Rothstein, L. R. (1995). The empowerment effort that came undone. The Journal of Product Innovation Management, 4(12), 347-348.

Sahinidis, A. G., \& Bouris, J. (2008). Employee perceived training effectiveness relationship to employee attitudes. Journal of European Industrial Training, 32(1), 63-76.

Safavi, A. A. (2008). Developing countries and e-learning program development. Journal of Global information technology management, 11(3), 47-64.

Sims, R. R. (2002). Organizational success through effective human resources management. Greenwood publishing group.

Sultana, M. (2013). Impact of Training in Pharmaceutical Industry: An Assessment on Square Pharmaceuticals Limited, Bangladesh'. International Journal of Science and Research, 2(2), 576-587.

Swart, J., Mann, C., Brown, S., \& Price, A. (2012). Human Resource Development. Routledge.

Scott, W. D. (1954). Personnel management: Principles, practices, and point of view.

Tahir,N. \& Yousafzai,kh.et al (2014). International Journal of Academic Research in Business and Social Sciences April 2014, Vol. 4, No. 4 ISSN: 2222-6990

Wagner, S. (2000). Retention: finders, keepers. Training \& Development, 54(8), 64-64. 


\section{QALAAI ZANISTSCIENTIFIC JOURNAL}

A Scientific Quarterly Refereed Journal Issued by Lebanese French University - Erbil, Kurdistan, Iraq

Vol. (5), No (2), Spring 2020

ISSN 2518-6566 (Online) - ISSN 2518-6558 (Print)

Wright, P. C., \& Geroy, G. D. (2001). Changing the mindset: the training myth and the need for world-class performance. International Journal of Human Resource Management, 12(4), 586-600.

فواز بن حسن محمد أبوملحه (2015): دور التدريب في تطوير الأداء الوظيفي لمنسوبي الشرطة

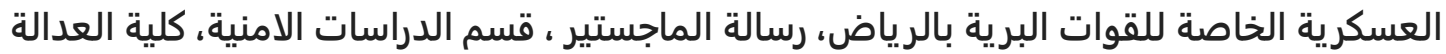

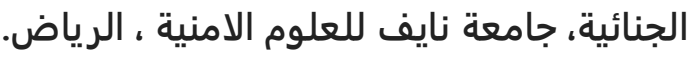

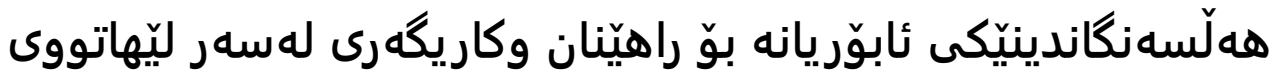

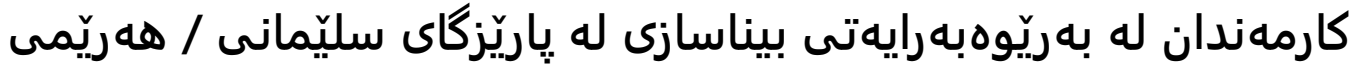 كوردستان}

يـوختـه:

راهينان ريّكا و هوّكاريّكى گرنكه بوّ رهخساندن و دروستكردنى زيان و كوزهرانيّكى باشتر بوّ فهرمابهران وكريّكارن لهلايهك و باشكرنى بارودوّخى ريّكخراو و دامهزراوهكان لهلايهكى ترهوه. ئامانجى سهرهكى ئهم توَيْزينهوه بريتى يه له خستنهرووى كاريگهرى راهيّنان لهسهر ئهدا و لِّهاتووى فهرمانبهر و كريّكاران. وه يرسيارى سهرهكى لهم تويّزينهوهيه بريتى يه له " ئايا راهيّنان كاريكهرى بهرجاوى ههيه لهسهر ئهداى فهرمانبهران وكريّكاران له بهريّوبهرايهتى بيناسازى له ياريّزكاى سليّمانى - ههريمى كوردستان"؟ بوّ بهديهينانى ئهو ئامانجه و وهلّامدانهوهى ئهو يرسياره، ئهم تويّزينهوهيه

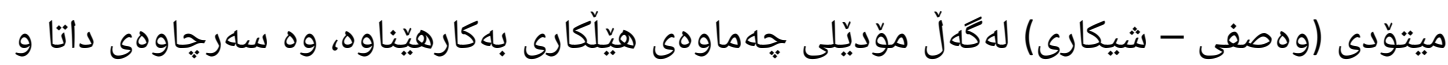
زانياريهكان له فوّرمى رايرسى يهوه وهركيراوه كه سهيلّهكهى بريتى بوه له (70 فهرمانبهر و كريّكار) له بهريّوبهرايهتى بيناسازى له ياريزّگاى سليّمانى ـ دهرئهنجامى تويّزينهوهكه ئهوهى بهديارخستوه كه يروّسهى راهيّنان كاريكهرى يوّزهتيف و مهعنهوى ههيه لهسهر ئهداى فهرمانبهران و كريّكاران وه ريّزهى وهلامدانهوهكه بريتى يه له (0.76) له ئاستى مهعنهوى (0.000)، ئهمهش ئهوه دهكهيهنيّت 


\section{QALAAI ZANISTSCIENTIFIC JOURNAL}

A Scientific Quarterly Refereed Journal Issued by Lebanese French University - Erbil, Kurdistan, Iraq

Vol. (5), No (2), Spring 2020

ISSN 2518-6566 (Online) - ISSN 2518-6558 (Print)

زيادكردنى ئاستى راهيّنان به ريّزهى له (1\%) دهبيّته هوّى زيادكردنى ئهداى فهرمانبهران و كريّكاران

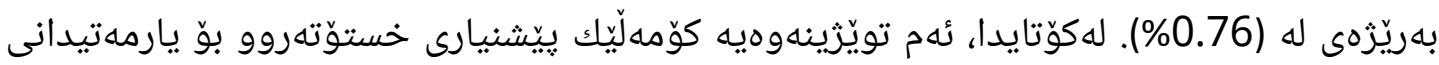
بهريّوبهرى بهريّوبهرايهتى بيناسازى له ياريّزكاى سليّمانى، لهكرنكترينيان يِيويسته خولى راهيّنانى ههمهجوَر به شيّوهيهكى ريّك و يِيّك و بهردهوام بوّ فهرمابهران و كريّكاران بكريّتهوه بهمهبهستى هي بهديهيّنانى ئارهزووى فهرمانبهران و بهرزكردنهوهى ئاستى ئهداو ليّهاتوويى كريّكاران. سيوفر التدريب فرص لعاملين و الموظفين من أجل الحصول على حياة مهنية أفضل والحصول على وضع أفضل في المنظمة. يهدف هذا البحث بيان تأثير التدريب على أداء العاملين و الموظفين. و الاسئلة الرئيسية في البحث " هل ان التدريب له تأثير حيوي على أداء العاملين و الموظفين في مديرية المبانى في محافظة السليمانية - إقليم كوردستان"؟ ولتحقيق هذا الهدف و الاجابة على هذا الأسئلة ، تم الاعتماد على المنهج (الوصفي - التحليلي) وبأستخدام نموذج الانحدار الخطي ، و ذلك لتحليل البيانات التى تم الحصول عليها من استمارة الاستبانة الموزعة على (70 من الموظفين و العاملين) الذين يعملون في مديرية المبانى في محافظة السليمانية للتعرف على أرائهم و مقترحاتهم فيما يخص بدور التدريب في تحسين ادائهم ـ وتبين النتائج أن عملية التدريب وابعاده له تأثير ايجابي و معنوي على أداء الموظفين و العاملين في مديرية المبانى في محافظة السليمانية و قيمة معامل الانحدار هو (0.76) عند المستوى المعنوي(0.000) ، مما يشير إلى أن الزيادة في مستوى التدريب بنسبة واحد بالمائة ، يزيد من أداء الموظفين و العاملين بنسبة (0.76) بالمائة. وفي الختام ، يقدم البحث بعض المقترحات لمساعدة مدير مديرية المبانى في محافظة السليمانية، منها ضرورة توفير مستويات منتظمة ومتنوعة من التدريب لتحقيق رغبات الموظفين و العاملين ورفع أدائهم 


\section{QALAAI ZANISTSCIENTIFIC JOURNAL}

A Scientific Quarterly Refereed Journal Issued by Lebanese French University - Erbil, Kurdistan, Iraq

Vol. (5), No (2), Spring 2020

ISSN 2518-6566 (Online) - ISSN 2518-6558 (Print)

\section{تقييم اقتصادي للتدريب وتأثيره في أداء العاملين في مديرية الانشاء

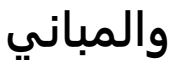 \\ في محافظة السليمانية - إقليم كوردستان}

الملخص:

سيوفر التدريب فرص لعاملين و الموظفين من أجل الحصول على حياة مهنية أفضل والحصول على

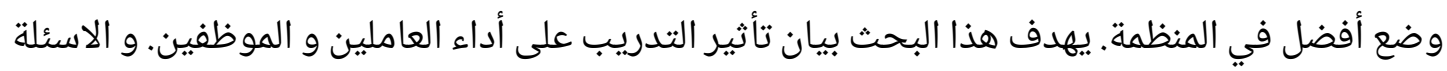

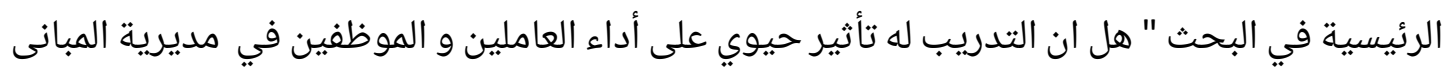
في محافظة السليمانية - إقليم كوردستان"؟ ولتحقيق هذا الهدف و الاجابة على هذا الأسئلة ، تم

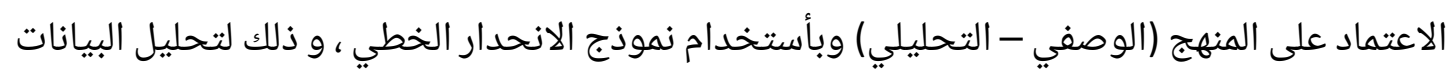
التى تم الحصول عليها من استمارة الاستبانة الموزعة على (70 من الموظفين و العاملين) الذين يعملون

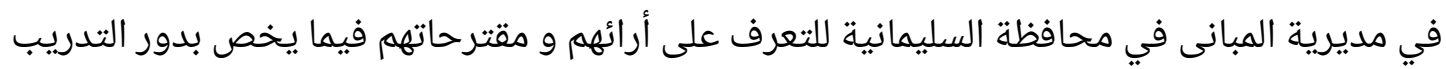
في تحسين ادائهم ـ وتبين النتائج أن عملية التدريب وابعاده له تأثير ايجابي و و معنوي على إنى أداء الموظفين و العاملين في مديرية المبانى في محافظة السليمانية و قيمة معامل الانحدار هو (0.76)

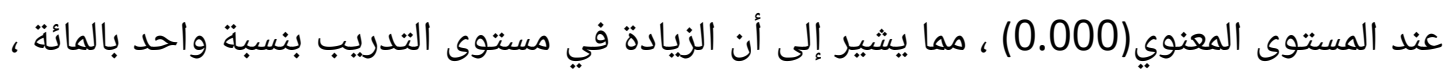

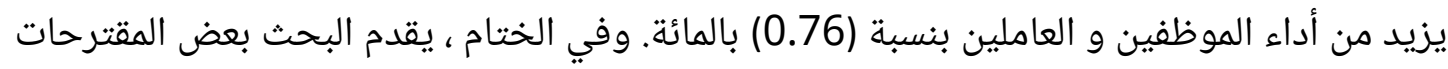

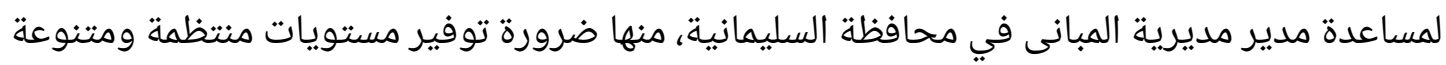

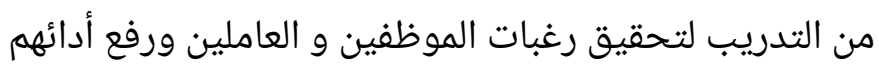

